\title{
Mantle thermal pulses below the Mid-Atlantic Ridge and temporal variations in the formation of oceanic lithosphere
}

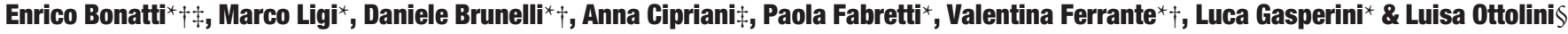 \\ * Istituto di Scienze Marine, Geologia Marina, CNR, Via Gobetti 101, 40129, Bologna, Italy \\ $\dagger$ †ipartimento di Scienze della Terra, Università "La Sapienza", Piazzale Aldo Moro 5, 00187, Rome, Italy \\ $\ddagger$ Department of Earth and Environmental Sciences, Lamont Doherty Earth Observatory, Columbia University, Palisades, New York 10964, USA \\ $\$$ Istituto di Geoscienze e Georisorse, Sezione di Pavia, CNR, Via Ferrata 1, 27100, Pavia, Italy
}

A 20-Myr record of creation of oceanic lithosphere at a segment of the central Mid-Atlantic-Ridge is exposed along an uplifted sliver of lithosphere. The degree of melting of the mantle that is upwelling below the ridge, estimated from the chemistry of the exposed mantle rocks, as well as crustal thickness inferred from gravity measurements, show oscillations of $\sim 3-4$ Myr superimposed on a longer-term steady increase with time. The time lag between oscillations of mantle melting and crustal thickness indicates that the solid mantle is upwelling at an average rate of $\sim 25 \mathrm{~mm} \mathrm{yr}^{-1}$, but this appears to vary through time. Slow-spreading lithosphere seems to form through dynamic pulses of mantle upwelling and melting, leading not only to along-axis segmentation but also to across-axis structural variability. Also, the central Mid-Atlantic Ridge appears to have become steadily hotter over the past 20 Myr, possibly owing to north-south mantle flow.

The oceanic lithosphere covers two-thirds of our planet: understanding how it forms and evolves is a major challenge in the Earth sciences. It is generally agreed that the oceanic lithosphere forms along mid-ocean ridges, where mantle material upwells and undergoes decompression and partial melting. The melt rises rapidly and freezes, producing the crust, while the peridotitic residue forms the lithospheric mantle. Mid-ocean-ridge topography, structure and composition indicate that near zero age processes of lithosphere formation vary along ridge axis ${ }^{1-3}$. Less is known, however, of how these processes vary through time, a question important for our understanding of how ocean basins evolve. Variations through time of the thermal regime and/or composition of a mid-ocean ridge should be recorded in lithosphere lying at increasing distances from the ridge axis along sea-floor spreading flow lines. However, older lithosphere is normally covered by sediment and not easily accessible to high-resolution observation and sampling.

An uplifted sliver of oceanic lithosphere (Fig. 1), exposing in the central Atlantic an $\sim 20$-Myr-long record of creation of lithosphere at a segment of the Mid-Atlantic Ridge (MAR), gave us the opportunity to investigate the temporal variability in the formation of lithosphere, to estimate the upwelling velocity of the mantle below the ridge, and to determine whether passive or dynamic models of creation of oceanic lithosphere prevail at slow-spreading ridges.

\section{A sliver of exposed oceanic lithosphere}

A major topographic anomaly, the Vema transverse ridge, runs on the southern side of the Vema transform, which offsets the MAR by $310 \mathrm{~km}$ at $\sim 11^{\circ} \mathrm{N}$ (Fig. 1). Its exposed northern scarp (that is, the southern wall of the transform valley) reaches in height up to $4 \mathrm{~km}$ above the valley floor (Fig. 2). Submersible ${ }^{4}$ multibeam $^{5}$ and seismic reflection data, and bottom samples (Fig. 1) revealed that the northern side of the Vema transverse ridge exposes a $\sim 3-4-\mathrm{km}$ thick, relatively complete and tectonically undeformed upper lithospheric section (Vema lithospheric section, VLS). The VLS consists of a $\sim 1 \mathrm{~km}$ mantle peridotite basal unit, overlain by a gabbroic unit, then by a dyke complex and topped by pillow basalt. In contrast, the southern slope of the transverse ridge exposes only upper crustal basalt (Fig. 2). The VSL is the edge of a slab of oceanic lithosphere that was flexured and uplifted between 10 and $12 \mathrm{Myr}$ $\mathrm{ago}^{6}$, and is now exposed continuously for at least $300 \mathrm{~km}$ along a sea-floor-spreading flow-line. This corresponds to a time interval of roughly $20 \mathrm{Myr}$, if we assume that this lithosphere formed at the eastern MAR segment (EMARS) that meets the Vema fracture zone from the south (Fig. 1), with no ridge jumps during this interval. Spreading half rates, estimated from plate motion reconstructions ${ }^{7}$, are $13.6 \mathrm{~mm} \mathrm{yr}^{-1}$ between 0 and $10 \mathrm{Myr}$ ago, $16.9 \mathrm{~mm} \mathrm{yr}^{-1}$ between 10 and $19 \mathrm{Myr}$ ago, and $17.2 \mathrm{~mm} \mathrm{yr}^{-1}$ between 19 and $26 \mathrm{Myr}$ ago. Crustal ages cited here are estimated assuming these rates.

We investigated lateral (that is, temporal) variations of lithospheric thermal structure and composition along the VLS through two independent approaches: (1) geochemistry of rocks obtained by systematic sampling; and (2) satellite and shipboard gravimetry.

\section{Temporal variations of degree of melting}

We sampled systematically the lower unit of the VLS at a maximum horizontal spacing of $\sim 10 \mathrm{~km}$, along a stretch of $250 \mathrm{~km}$, that is, $\sim 15 \mathrm{Myr}$ (Figs 1 and 3). We obtained ultramafic rocks at all sites below $4 \mathrm{~km}$ depth, that is, within the lower $1 \mathrm{~km}$ portion of the section. Serpentinized protogranular/porphyroclastic peridotites prevail; they contain olivine, orthopyroxene (opx), clinopyroxene (cpx) and spinel (sp) as relict mantle-equilibrated minerals. They are generally similar to ultramafics sampled elsewhere along midocean ridges, considered to be the residue from various extents of partial melting that took place below the ridge axis ${ }^{8-10}$.

We determined by electron probe the major-element composition of mantle-equilibrated phases opx, cpx and spinel from more than 50 ultramafic rocks. Opx and cpx were also analysed for trace 


\section{articles}

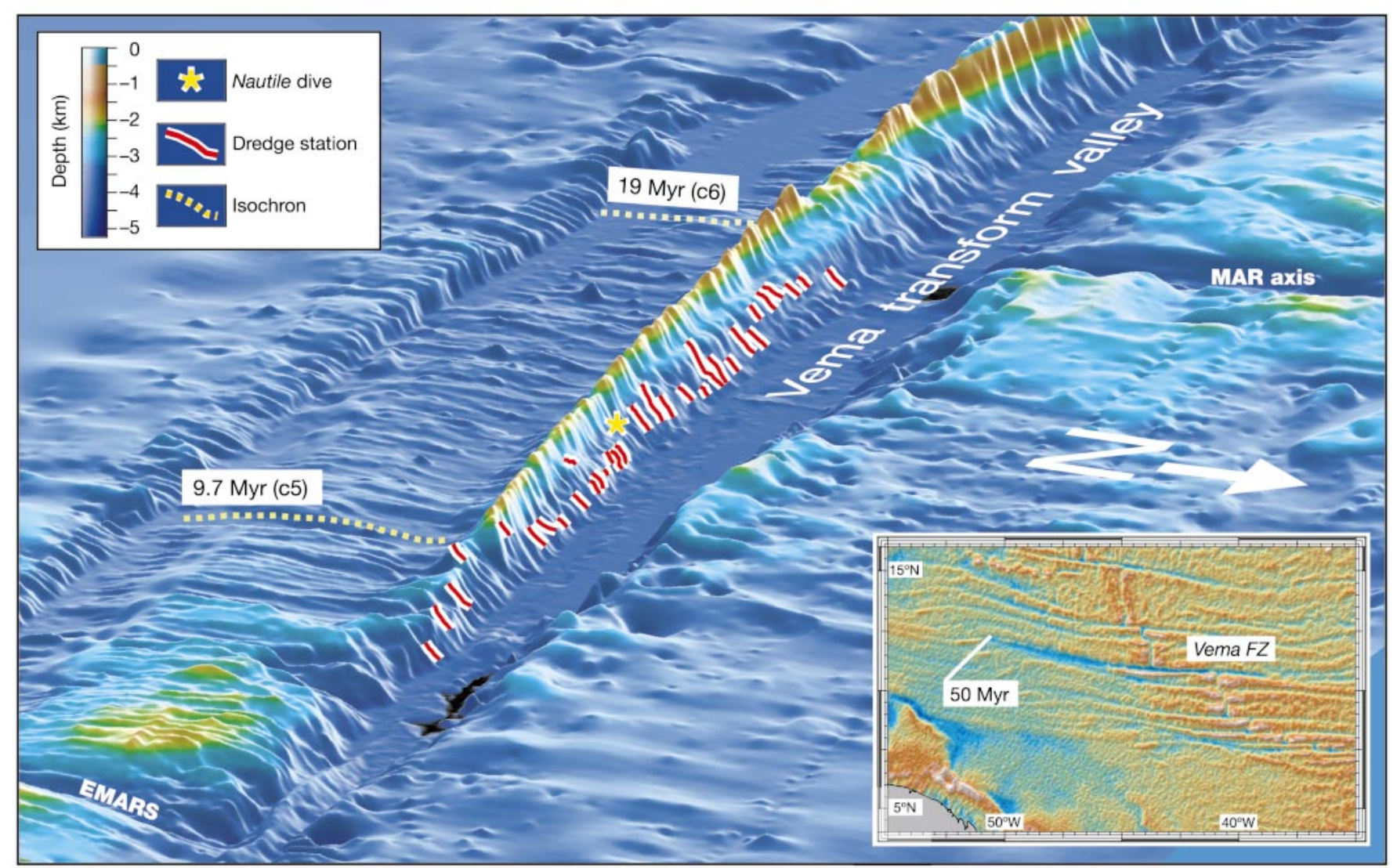

Figure 1 The Vema transform region viewed from the northeast. Figure is based on multibeam data obtained during cruises EW9305 (ref. 5), and S-19 and S-22 (RV Akademik N. Strakhov). The Vema lithospheric section (VLS) is clearly visible. Location of magnetic chrons C5 and C6, of the Nautile submersible profiles, and of the rocks sampled along the VLS, are indicated. The inset shows a satellite-derived gravity image of the Central Atlantic, where the Vema fracture zone (FZ), the transverse ridge and the longlived EMARS can be identified.

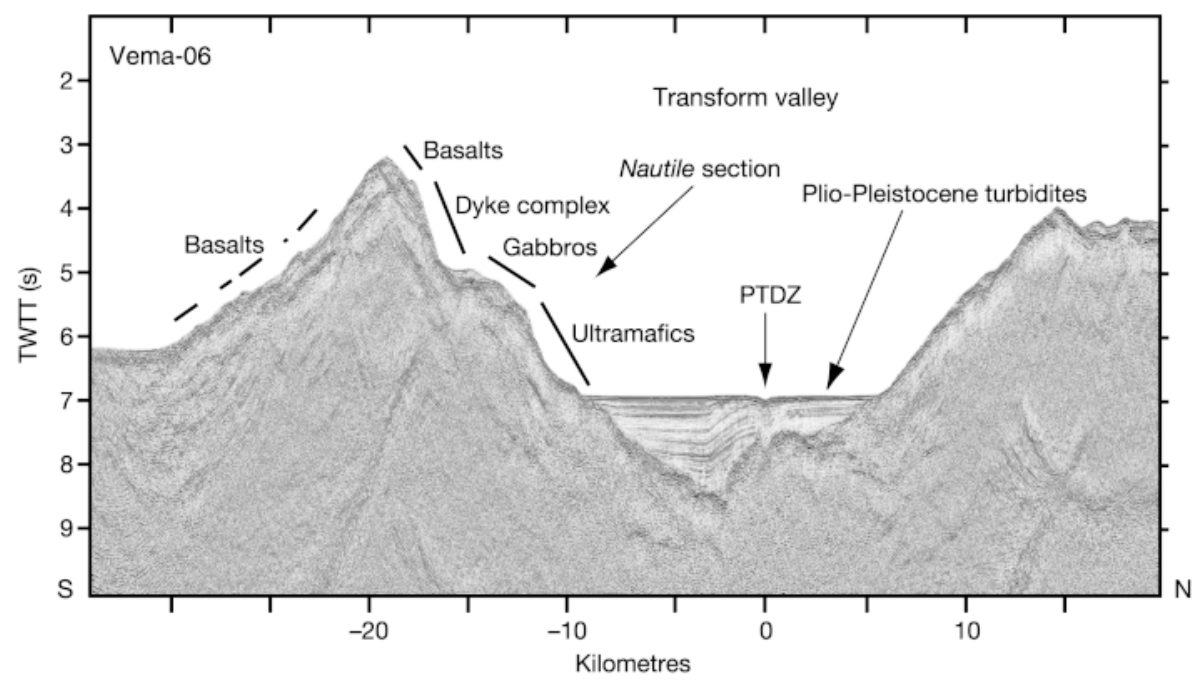

Figure $2 \mathrm{~N}-\mathrm{S}$ multichannel seismic reflection profile (Vema-06) perpendicular to the Vema transform, above the Nautile submersible sections. Profiles were obtained by the RV Explora using as sound source a tuned array of 28 air-guns (total volume of 60 litres, working pressure of 2,000 p.s.i.) towed $6 \mathrm{~m}$ below sea level, and as receiver a 3,150 $\mathrm{m}$ long streamer (120 channels spaced $25 \mathrm{~m}$ apart) towed $12 \mathrm{~m}$ deep. Lithology of the VLS is based on submersible observations and sampling. A reflector roughly parallel to the southern slope of the Vema transverse ridge, about $0.5 \mathrm{~s}$ (two-way travel time, TWTT) below the sea floor, can be traced to the northern slope, where the boundary basalt/dyke complex was observed by submersible. This reflector probably marks the sub-bottom geometry of this boundary. PTDZ (Principal Transform Displacement Zone) points to the trace of strike-slip motion in the sediments filling the transform valley. North of this trace is the African plate; south of this trace is the South American plate. 
elements by ion probe. The chromium number $(\mathrm{Cr} \#=100 \mathrm{Cr} /$ $(\mathrm{Al}+\mathrm{Cr}))$ of opx and spinel can be interpreted in terms of extent of melting undergone by these mantle rocks; this is because, during melting, Al partitions with the melt while $\mathrm{Cr}$ stays with the residue $^{11-13}$. We excluded spinels affected by secondary reactions with melts or fluids ${ }^{14}$. The $\mathrm{Ti} / \mathrm{Zr}$ ratio of cpx can also be used to estimate degree of melting, because of the different partition coefficients of $\mathrm{Ti}$ and $\mathrm{Zr}$ during melting ${ }^{10}$. We calibrated our spinel and opx Cr\# data in terms of degrees of melting assuming as a source a fertile, pyrolite-like peridotite ${ }^{13,15}$. Degrees of melting calculated from Ti/Zr of cpx and from Cr\# of opx and spinel correlate. They range along the VLS from $5.7 \%$ to $14.3 \%$, with oscillations where the degree of melting appears to increase gradually and then decreases rapidly. These short-wavelength oscillations are superimposed on a long-term $(>15 \mathrm{Myr})$ trend of increasing degree of melting with time, estimated on a regression line to range from $7 \pm 1.5 \%$ about $19 \mathrm{Myr}$ ago, to $13 \pm 2 \%$ about $4 \mathrm{Myr}$ ago (Fig. 3).

Given that the crust consists of frozen basaltic melt extracted from the mantle, and assuming no secondary crustal thinning (for instance, by core-complex tectonics), temporal variations of extent of melting should be reflected by variations of crustal thickness ${ }^{16}$, as discussed next.

\section{Variations of gravity and crustal thickness}

We compiled a free-air gravity map from a total of 31,872 shipboard gravity measurements, and combined this map with free-air gravity data obtained by satellite altimetry ${ }^{17,18}$. The calculated mantle Bouguer anomaly (MBA) shows a prominent negative circular zone centred on the EMARS (Fig. 4c), consistent with the 'bull's eye' MBA pattern detected elsewhere along the $\mathrm{MAR}^{2}$, reflecting thicker crust at the segment's centre. The MBA increases with age of the crust owing to cooling of the lithosphere. The thermal component of gravity, estimated assuming the present spreading rate (Fig. 4d), was subtracted from the $\mathrm{MBA}^{19}$; we thus obtained residual MBA (RMBA) images that reflect lateral variations of density and of crustal thickness (Fig. 4e). Given that lateral variations of crustal density are probably negligible, the RMBA reflects variations of crustal thickness (Fig. 4f). The RMBA pattern indicates a decrease of crustal thickness moving from the centre of the EMARS towards the Vema eastern ridge-transform intersection (RTI), and a minimal crustal thickness along the southern edge of the transform valley (Fig. 4), consistent with seismic refraction experiments ${ }^{20,21}$. RMBA profiles along a flow line from the centre of the EMARS show (1) a long-range steady increase of crustal thickness from $\sim 20$-Myrold crust to the present (note that this pattern of steady crustal thickening would be enhanced if we were to take into account the

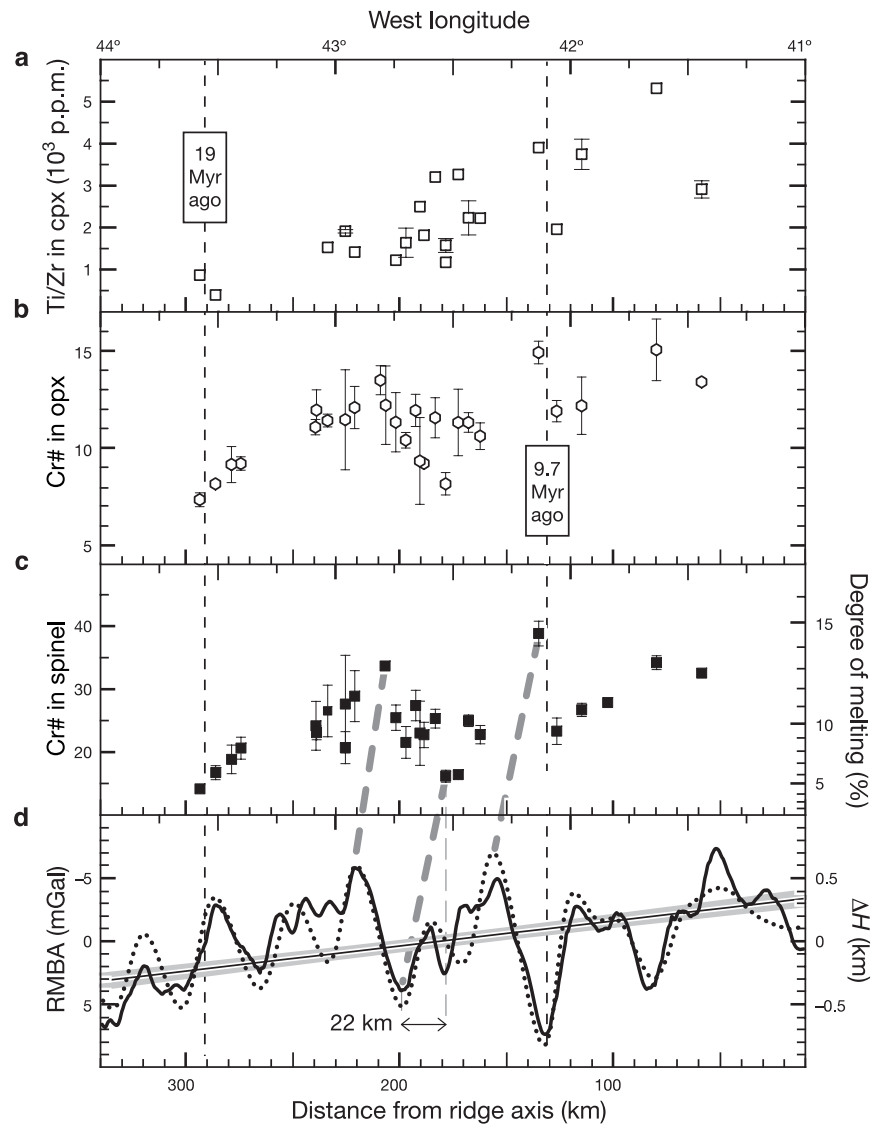

Figure 3 Temporal variations of mantle degree of melting and of crustal thickness. a-c, Lateral variations of Ti/Zr in cpx and Cr\# in opx and spinel of mantle-derived peridotites sampled along the VLS. These curves, interpreted as reflecting variations of degree of melting, correlate $(R \mathbf{a}, \mathbf{b}=0.81 ; R \mathbf{b}, \mathbf{c}=0.97)$. Major element mineral compositions were determined with a JEOL JXA 8600 and a CAMECA SX-100 electron probe; trace elements were determined with a CAMECA IMS $4 \mathrm{~F}$ ion probe, using standard techniques. d, RMBA (thick solid line) and inferred variations of crustal thickness $\Delta H$ (dotted line) along the mid-point trace of EMARS shown in Fig. 4e. RMBA regression line (95\% confidence interval) shows thickening of the crust moving towards the ridge axis.
The RMBA signal (scale inverted), indicating crustal thickness temporal variations, has been cross-correlated with the curve representing extent of melting of the peridotites. The maximum of the cross-correlation function $(r)$ is reached when the RMBA curve is shifted eastward by $22 \mathrm{~km}\left(r_{0}=-0.1, r_{\max }=0.7\right)$. This is a good correlation, considering that geochemical and gravity data are from different locations along the ridge segment, that rock samples are not uniformly distributed, and that gravity was measured at sea level, with strong attenuation of high frequencies. Dashed lines in $\mathbf{c}$ and $\mathbf{d}$ show the suggested shift. Crustal ages based on ref. 7 . 
observed variations of spreading rate in correcting for the thermal component of gravity); (2) 3-4-Myr-long oscillations of crustal thickness, superimposed on the steady thickening. Each oscillation in the RMBA signal can be interpreted as reflecting a gradual increase of crustal thickness for $\sim 3-4 \mathrm{Myr}$, followed by a rapid decrease (Fig. 3d).

The temporal variations of crustal thickness shown by the RMBA correlate with the variations in the mantle's degree of melting inferred from the peridotites, provided that the crustal thickness pattern is shifted eastward by $\sim 22 \mathrm{~km}$ along the VLS (Fig. 3 ). This shift must reflect the different upwelling velocities of the melt and of the solid residue, allowing us to estimate the velocity of mantle advection below ridge axis.

\section{Velocity of mantle upwelling}

We estimated mantle advection velocity assuming rapid melt extraction and rise from the melting zone below the ridge axis, in line with uranium-series disequilibrium data suggesting melt upwelling velocities of metres per year ${ }^{22-24}$. When the melt freezes near the sea floor, forming the crust, and starts moving laterally with the plate, its parent mantle will be starting its slow ascent from the melting depth (Fig. 5). When this mantle parcel is incorporated in the lithosphere and starts moving laterally, the basalt it generated is further along the spreading path. The horizontal distance along the lithospheric section between the basalt and its parent mantle, translated as time, approximates the time it took for the residual mantle to travel from the melting depth to the lithosphere.

The $\sim 22-\mathrm{km}$ westward displacement of the curve representing temporal variations of crustal thickness relative to the curve representing extent of melting of the mantle peridotites (Fig. 3) is equivalent to $\sim 1.3 \mathrm{Myr}$. This is approximately the time it took a parcel of mantle to rise from the melting depth to the lithosphere. Applying the equations of ref. 25, we estimate an average depth of melting below the EMARS of $\sim 35 \mathrm{~km}$; the mantle average upwelling rate from the melting depth is then $\sim 24.8 \mathrm{~mm} \mathrm{yr}^{-1}$, that is, significantly higher than the $15.6 \mathrm{~mm} \mathrm{yr}^{-1}$ average half spreading rate. Based on mid-ocean-ridge basalt (MORB) uranium-series disequilibrium data, solid mantle upwelling rates of $25 \mathrm{~mm} \mathrm{yr}^{-1}$ were estimated in the Juan de Fuca ridge ${ }^{24}$ similar to spreading halfrate $\left(30 \mathrm{~mm} \mathrm{yr}^{-1}\right)$.

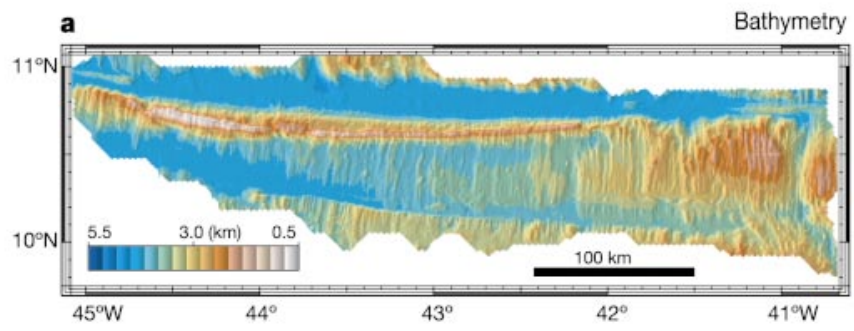

b
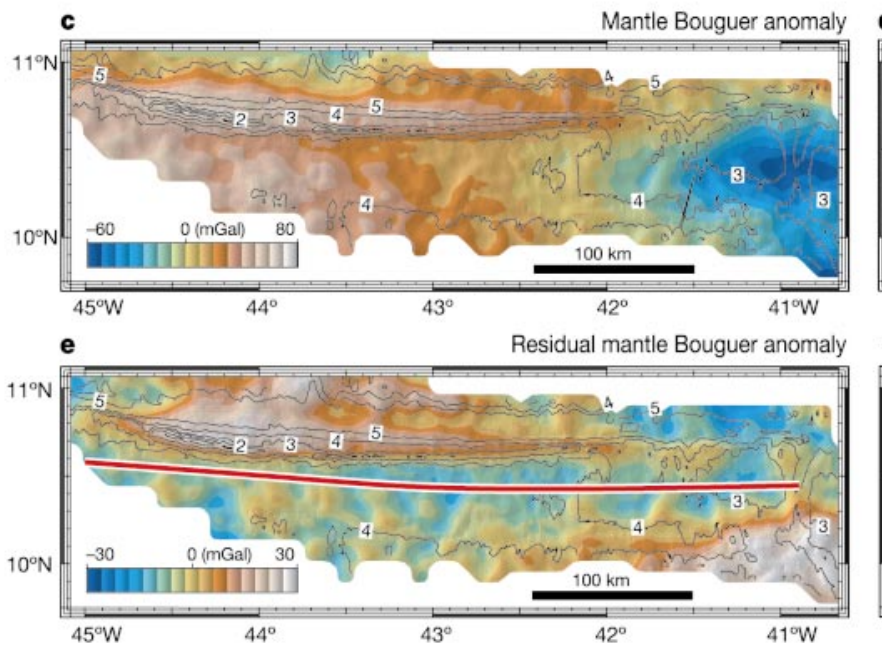

\section{f}

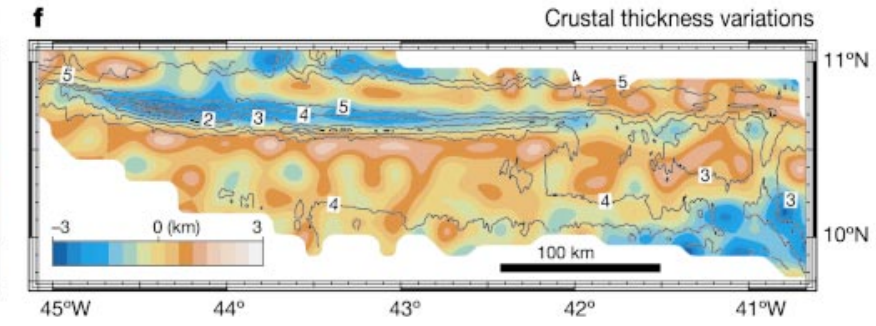

Figure 4 Gravity imagery in the Vema transform region. Shipboard gravity measurements, obtained during cruises EQUAP, C1702, V3206, K020A (ref. 48) and EW9305 (ref. 5), were corrected with the techniques outlined in ref. 49 leading to an accuracy of $2.6 \mathrm{mGal}$, with $95 \%$ confidence that anomalies $>5 \mathrm{mGal}$ are real and not noise. These data were combined with free-air gravity data obtained by satellite altimetry ${ }^{17}$ making use of inputoutput system theory ${ }^{18}$ in order to avoid edge effects in the computation of the MBA, due to lack of shipboard data outside the region of interest. $\mathbf{a}$, Shaded relief image based on multibeam data. Mercator projection at $10^{\circ} \mathrm{N}$. b. Sediment isopach map based on our multichannel seismic reflection profiles complemented by single-channel data described in ref. 48. Reflection times were converted to depths assuming uniform P-wave velocity of $2 \mathrm{~km} \mathrm{~s}^{-1}$ throughout the sedimentary column. Bathymetric contours (interval, $1 \mathrm{~km}$ ) mark the position of fracture zones and rift valleys. c, MBA map (zero level is arbitrary) generated by subtracting from the observed free-air anomalies the attraction of sea-floor topography and sediments, and of the crust-mantle interface, assuming 5-km-thick crust, and densities of $1,040,1,900,2,690$ and $3,330 \mathrm{~kg} \mathrm{~m}^{-3}$ for sea water, sediments,

crust and mantle, respectively. d, Predicted gravity anomalies due to density variations caused by mantle thermal structure. Mantle temperatures were estimated by solving the steady-state advection-diffusion heat equation assuming $0{ }^{\circ} \mathrm{C}$ at the sea floor and $1,350^{\circ} \mathrm{C}$ at $100 \mathrm{~km}$ of depth, using a three-dimensional domain of mantle flow calculations, with variable grid spacing $(512 \times 256 \times 101)$, and highest grid resolution at the plate boundaries ${ }^{32}$. Density changes due to temperature were calculated assuming a thermal expansion coefficient of $3.25 \times 10^{-5} \mathrm{per}^{\circ} \mathrm{C}$, chosen to match an averaged MBA profile, in a least-squares sense, along a $30-\mathrm{km}$-wide corridor centred on a flowline from EMARS midpoint. Mantle flow velocities were estimated assuming steady-state platethickening passive flow ${ }^{33}$. e, Residual anomaly map. Thick red line marks the palaeomidpoint trace of the EMARS. f, Inferred crustal thickness obtained after downward continuation of a low-pass filtered set (features with wavelength $<25 \mathrm{~km}$ were filtered out) of the computed residual anomalies to a depth of $9 \mathrm{~km}$ below sea level, assuming a crust-mantle density contrast of $640 \mathrm{~kg} \mathrm{~m}^{-3}$. 

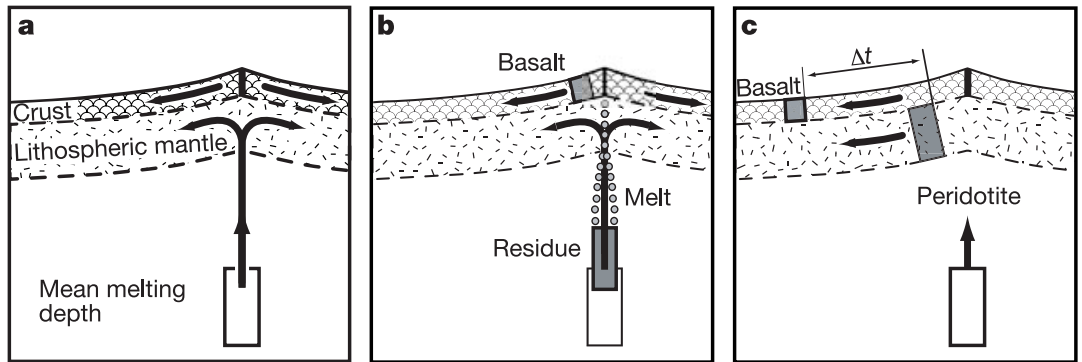

Figure 5 Differential upwelling of melt and of solid residual mantle beneath the ridge. Figure shows how a parcel of basaltic crust is displaced laterally relative to its parent mantle, and how mantle upwelling velocity can be estimated. $\mathbf{a}$, Melting starts in the upwelling mantle within the melting interval. $\mathbf{b}$, The melt rises rapidly and freezes, forming the basaltic crust, while the solid residual peridotitic mantle continues to rise. c, When the

However, peridotite geothermometry suggests that upwelling rates below the EMARS varied through time. Geothermometry calculations based on two pyroxene and single cpx equilibria in the VLS peridotites ${ }^{26}$ showed equilibration temperatures that appear to correlate with the degree of melting. Equilibration temperatures are probably affected by the cooling rate of the system during ascent, which determines the extent to which coexisting phases can reach equilibrium at a given temperature; they are therefore related to the mantle's advection velocity, with higher values during faster upwelling ${ }^{27}$. Therefore, the variations of equilibration temperatures we found along the VLS are probably related to variations of advection velocity below the ridge, with higher velocity associated with higher degree of melting.

\section{Passive versus dynamic mantle upwelling and melting}

We now seek to explain first, the short-wavelength (3-4-Myr) residual peridotitic mantle joins the lithosphere and starts moving laterally with the plate, the basaltic crust it generated has moved further on with the plate. The distance between the basalt and its parent mantle, converted to time, approximates the time it took the peridotite to travel from the melting interval to the lithospheric plate.

oscillations of the mantle's degree of melting as it upwells below the EMARS, and of the thickness of the crust created at that segment; and second, the long-term $(\sim 20-\mathrm{Myr})$ steady increase of the mantle's degree of melting and of crustal thickness. Any interpretation must take into account the fact that the VLS (along which the variations of the mantle's extent of melting were estimated) formed originally towards the northern edge of the $\sim 80$ km-long EMARS, whereas variations of crustal thickness were estimated along a spreading flow line from the midpoint of the segment (Fig. 4e). Current models of slow-spreading mid-ocean ridges call for magma injection to be highest towards the centre of a segment ${ }^{28,29}$, consistent with the 'bull's-eye' negative MBA (Fig. 4c) centred on the EMARS.

The fluctuations of magma supply inferred from the oscillations of crustal thickness can result from two processes: (1) periodic magma pulses at the surface ('magma solitons'), even when melt

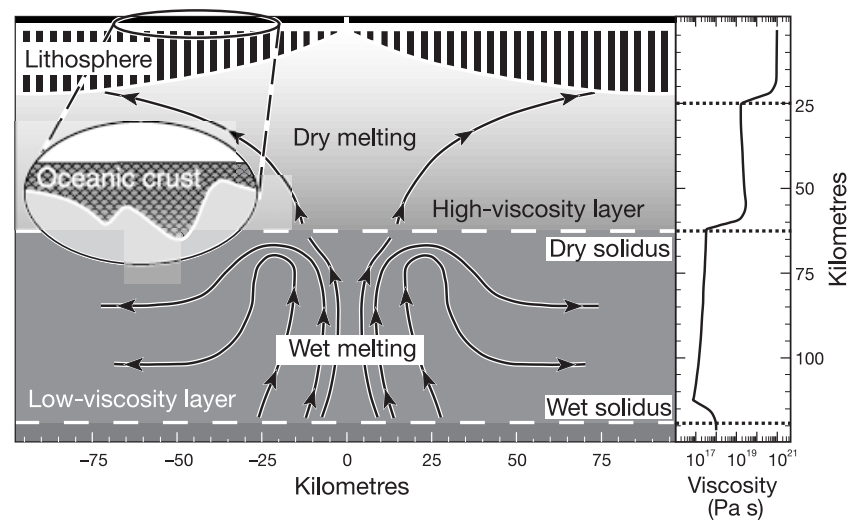

Figure 6 Model of mantle upwelling and crustal accretion consistent with the observed variations of extent of melting and crustal thickness at the EMARS. Arrows show direction of mantle flow. This crustal accretion pattern results from mantle upwelling induced by non-uniform sub-ridge mantle rheology, with a low-viscosity layer between two layers with higher viscosities ${ }^{42}$. The viscosity profile (right panel) describes the effects of dehydration, of melt in the matrix, and of change in creep mechanism. Water in the oceanic upper mantle deepens the peridotite solidus and the zone of partial melting relative to anhydrous mantle. Melt productivity during hydrous melting in the low-viscosity layer is low (1-2\%); after water exhaustion melting continues above the 'dry solidus' in the high-viscosity layer, with higher melt production rates ${ }^{40,41}$. High viscosity precludes compositional and thermal buoyant flow in the dry melting region, where solid flow is mostly driven by plate separation (corner flow). The low-viscosity layer favours intermittent plume-like enhanced upwelling and melting.

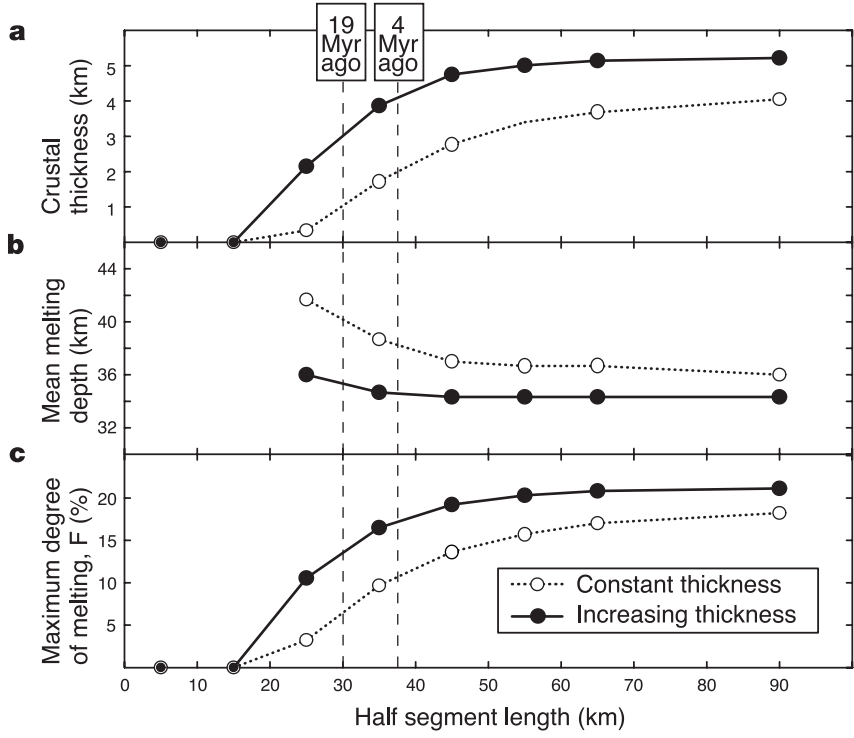

Figure 7 Extent of melting versus ridge half segment length when a ridge intersects a long-offset slow-slip transform such as Vema. a, Crustal thickness; $\mathbf{b}$, mean melting depth; $\mathbf{c}$, maximum degree of melting. Numerical experiments on melt production at ridge segment midpoint were based on ref. 50, using either constant or increasing lithospheric thickness passive-flow models. The length of the EMARS increased from 60 to $76 \mathrm{~km}$ during the time interval covered by our study, that is, from 19 to 4 Myr ago. The lithosphere thickening model appears to fit our data better. 
production in the mantle is constant ${ }^{30}$; and (2) fluctuations in extent of melting at the mantle source.

As we found variations not only of crustal thickness but also of the mantle's degree of melting (Fig. 3), the thermal structure and/or composition of the upwelling mantle must have varied through time. We infer a constant composition of the mantle source, based on the nearly constant $\mathrm{Nd}$ isotopic ratio and degree of enrichment shown by basaltic glasses sampled along the VLS (A.C. et al., manuscript in preparation). Thus, both the short-wavelength oscillations and the long-term variation imply corresponding variations of mantle potential temperature and/or upwelling velocity.

We consider whether these results are compatible with a 'passive' model, where mantle upwelling and melting are caused solely by plate separation at ridge axis, or whether a dynamic component of mantle flow is required, driven by thermal and compositional buoyancy. Passive mantle flow is shaped by viscous drag from rigid plates that move apart. Predicted flow velocity is close to spreading half-rate, but is affected also by plate geometry close to the ridge axis ${ }^{31,32}$. Where the plate thickens rapidly with distance from ridge axis, upwelling is narrowly focused and vertical velocity can exceed the half spreading rate $^{33}$.

Dynamic flow models require low viscosities in the melting region, and buoyancy forces due to thermal and compositional lowering of density caused by melting, that is, by decrease in the residue of $\mathrm{Fe} / \mathrm{Mg}$ ratio and of dense phases such as garnet ${ }^{34-36}$.

\section{Short-wavelength oscillations}

Oscillations of crustal thickness with periods of a few Myr have also been inferred from gravity elsewhere in the $\mathrm{MAR}^{37,38}$; therefore, they may reflect general mechanisms of crustal formation at slowspreading ridges. Numerical models for slow ridges that include non-uniform mantle rheology and thermal and compositional buoyancy predict that melting, and consequently crustal thickness, undergo oscillations, the frequency and amplitude of which depend on mantle viscosity ${ }^{36,39}$.

The observed oscillations can be explained if we assume a subridge low-viscosity zone $\left(\sim 10^{18} \mathrm{~Pa} s\right)$ underlying a higher-viscosity layer ( $\sim 10^{20} \mathrm{~Pa} \mathrm{~s}$ ) (Fig. 6). This rheological stratification may be due to extraction of $\mathrm{H}_{2} \mathrm{O}$ from the upwelling mantle in the deeper part ( $>60 \mathrm{~km}$ ) of the melting interval ('wet melting' interval). $\mathrm{H}_{2} \mathrm{O}$, present in significant quantities $(\sim 0.1 \%)$ in the oceanic upper mantle ${ }^{40}$, partitions with the melt during 'wet melting', driving up the viscosity of the residue by two orders of magnitude ${ }^{40,41}$. The high-viscosity residue continues to upwell and undergoes 'dry' melting above $\sim 60 \mathrm{~km}$ (Fig. 6). High viscosity precludes dynamic mantle flow ${ }^{36}$, so solid flow within the upper layer is mostly driven by plate separation (passive flow). However, the low-viscosity layer allows compositional and thermal buoyant flow ${ }^{36,42}$. A possible model is that, as the mantle moves away from the ridge axis, it becomes denser owing to cooling and to the decreasing fraction of melt it contains because of the melt's upward migration, thus overcoming compositional buoyancy. According to numerical models, a dense plume forms and sinks periodically into the mantle, giving rise to intermittent convective rolls, periodic enhanced upwelling and increased temperature at the top of the low-viscosity layer, and, therefore, to increased melting below the ridge axis. The periodicity depends on the thickness of the low-viscosity layer ${ }^{42}$; its assumed thickness (Fig. 6) is consistent with our observed 3-4-Myr oscillations.

\section{Is the MAR becoming hotter?}

The observed long-term trend of the mantle's increasing degree of melting and of the thickening of the crust suggests that the mantle upwelling beneath the MAR has become gradually hotter over the past $20 \mathrm{Myr}$, during which the spreading half rate slowed down significantly ${ }^{7}$ (Fig. 3). We offer two explanations. The first calls for variations of the length of the EMARS with time. The second, of broader significance, implies long-term thermal pulses in the central Atlantic mantle. The first hypothesis is based on satellite gravity data (Fig. 1) showing a gradual lengthening of the EMARS since about $50 \mathrm{Myr}$ ago owing to changes in ridge/transform geometry related to a westward migration of the eulerian pole between Africa and South America. RMBA and segment length are related, the longest segments having the largest $\mathrm{RMBA}^{2,43,44}$. However, this correlation is interpreted as being due to stronger focusing of melt at segment midpoint in longer segments, while melt production appears to be independent of segment length ${ }^{45}$. Segment length is important, however, because midpoints of longer segments are least affected by the cold-edge effect of a long-offset transform. Numerical experiments on the mantle's degree of melting versus segment length when a segment meets a long-offset, slow-slip transform such as Vema, do indeed show increasing degrees of melting below the segment's centre as the segment lengthens (Fig. 7).

We prefer, however, the second explanation-that is, steady increase of mantle temperature below the MAR, resulting in increasing melt production despite decreasing spreading rates. The idea of a gradually hotter northern MAR is supported by crustal thinning with age elsewhere in the MAR between $29^{\circ}$ and $40^{\circ} \mathrm{N}$ (refs 38,45 ). MAR topography and geochemistry suggest an overall decrease of sub-ridge mantle temperature from the Iceland/ Azores swells to the equatorial 'cold' region. We speculate that the gradual heating of the MAR in the past 20 Myr may be related to hot sub-asthenospheric mantle flowing southward ${ }^{46}$, consistent with seismic anisotropy in the North Atlantic ${ }^{47}$.

\section{Summary}

Extending our results to slow-spreading ridges in general, we come to the following conclusions. (1) 3-4-Myr oscillations of degree of melting and crustal thickness are caused by intermittent buoyant 'active' convective upwelling, due to non-uniform mantle rheology beneath the ridge. Thus, the slow-spreading oceanic lithosphere is not only segmented along-axis; its structure also varies systematically normal to the ridge axis. (2) The solid mantle average upwelling velocity beneath the ridge can be significantly higher than the spreading half-rate, and can vary through time, being highest during intervals of high degree of melting. This supports the idea of an 'active' component in mantle advection and melting. (3) Much of the central MAR has become gradually hotter over the past $20 \mathrm{Myr}$, possibly owing to southward flow of hot mantle.

Received 8 October 2002; accepted 28 March 2003; doi:10.1038/nature01594.

1. Macdonald, K. C. et al. A new view of the mid ocean ridge from the behaviour of ridge axis discontinuities. Nature 335, 217-225 (1988).

2. Lin, J., Purdy, G. M., Shouten, H., Sempere, J. C. \& Zervas, C. Evidence from gravity data for focused magmatic accretion along the Mid-Atlantic Ridge. Nature 344, 627-632 (1990).

3. Phipps Morgan, J. \& Parmentier, E. M. Crenulated seafloor: Evidence for spreading-rate dependent structure of mantle upwelling and melting beneath a mid-oceanic spreading center. Earth Planet. Sci. Lett. 129, 73-84 (1995).

4. Auzende, J. M. et al. Direct observation of a section through slow-spreading oceanic crust. Nature 337, 726-729 (1989).

5. Kastens, K. et al. The Vema transverse ridge (Central Atlantic). Mar. Geophys. Res. 20, 533-556 (1998)

6. Gasperini, L. et al. Time constraints on the emplacement of an uplifted sliver of lithosphere at the Vema transverse ridge (Central Atlantic). J. Conf. Abstr. 4, 757 (1999).

7. Cande, S. C., LaBreque, J. L. \& Haxby, W. F. Plate kinematics of the south Atlantic, chron C34 to the present. J. Geophys. Res. 93, 13479-13492 (1988).

8. Dick, H. J. B., Fisher, R. L. \& Bryan, W. B. Mineralogic variability of the uppermost mantle along mid ocean ridges. Earth Planet. Sci. Lett. 69, 88-106 (1984).

9. Michael, P. J. \& Bonatti, E. Peridotite composition from the North Atlantic; regional and tectonic variations and implications for partial melting. Earth Planet. Sci. Lett. 73, 91-104 (1985).

10. Johnson, K. T. M., Dick, H. J. B. \& Shimizu, N. Melting in the oceanic upper mantle: An ion microprobe study of diopsides in abyssal peridotites. J. Geophys. Res. 95, 2661-2678 (1990).

11. Jaques, A. L. \& Green, D. H. Anhydrous melting of peridotite at $0-15 \mathrm{~kb}$ pressure and the genesis of tholeiitic basalts. Contrib. Mineral. Petrol. 73, 287-310 (1980).

12. Mysen, B. O. \& Kushiro, I. Compositional variations of coexisting phases with degree of melting of peridotite in the upper mantle. Am. Mineral. 62, 843-865 (1977).

13. Hellebrand, E., Snow, J. E., Dick, H. J. B. \& Hofmann, A. W. Coupled major and trace elements as indicators of the extent of melting in mid-ocean-ridge peridotites. Nature 410, 677-681 (2001).

14. Seyler, M. \& Bonatti, E. Regional-scale melt-rock interaction in lherzolitic mantle in the Romanche fracture zone (Atlantic Ocean). Earth Planet. Sci. Lett. 146, 273-287 (1997). 
15. Brunelli, D. Variazioni temporali nei processi di formazione di litosfera lungo le dorsali medio-oceaniche Thesis, Univ. Bologna (2001)

16. Forsyth, D. W. Crustal thickness and the average depth and degree of melting in fractional melting models of passive flow beneath mid-ocean ridges. J. Geophys. Res. 98, 16073-16079 (1993).

17. Sandwell, D. T. \& Smith, W. H. F. Marine gravity anomaly from Geosat and ERS-1 satellite altimetry J. Geophys. Res. 102, 10039-10054 (1997).

18. Li, J. \& Sideris, M. G. Marine gravity and geoid determination by optimal combination of satellite altimetry and shipborne gravimetry data. J. Geodesy 71, 209-216 (1997).

19. Kuo, B. Y. \& Forsyth, D. W. Gravity anomalies of the ridge-transform system in the South Atlantic between $31^{\circ}$ and $34.5^{\circ} \mathrm{S}$ : Upwelling centers and variations in crustal thickness. Mar. Geophys. Res. 10 205-232 (1988)

20. Louden, K. E., White, R. S., Potts, C. G. \& Forsyth, D. W. Structure and seismotectonics of the Vema fracture zone, Atlantic Ocean. J. Geol. Soc. Lond. 143, 795-805 (1986).

21. Potts, C. G., White, R. S. \& Louden, K. E. Crustal structure of Atlantic fracture zones: II, The Vema fracture zone and transverse ridge. Geophys. J. R. Astron. Soc. 86, 491-513 (1986).

22. Spiegelman, M. \& Kenyon, P. M. The requirements for chemical disequilibrium during magma migration. Earth Planet. Sci. Lett. 109, 611-620 (1992).

23. Spiegelman, M. \& Elliott, T. Consequences of melt transport for uranium series disequilibrium in young lavas. Earth Planet. Sci. Lett. 118, 1-20 (1993).

24. Lundstrom, C. C., Gill, J., Williams, Q. \& Perfit, M. R. Mantle melting and basalt extraction by equilibrium porous flow. Science 270, 1958-1961 (1995).

25. Langmuir, C. H., Klein, E. M. \& Plank, T. in Mantle Flow and Melt Generation at Mid-Ocean Ridge (eds Phipps Morgan, J., Blackman, D. K. \& Sinton, J. M.) 183-280 (Geophysical Monograph 71, American Geophysical Union, Washington D.C., 1992).

26. Taylor, W. R. An experimental test of some geothermometer and geobarometer formulations for upper mantle peridotites with application to the thermobarometry of fertile lherzolite and garnet websterite. Neues Jb. Mineral. Abh. 172, 381-408 (1998)

27. Lasaga, A. C. in Advances in Physical Geochemistry Vol. 3 (ed. Saxena, S. K.) 81-114 (Springer, New York, 1983).

28. Magde, L. S., Sparks, D. W. \& Detrick, R. S. The relationship between buoyant mantle flow, melt migration, and gravity bull's eyes at the Mid-Atlantic Ridge between $33^{\circ} \mathrm{N}$ and $35^{\circ} \mathrm{N}$. Earth Planet. Sci. Lett. 148, 59-67 (1997)

29. Magde, L. S., Barclay, A. H., Toomey, D. R., Detrick, R. S. \& Collins, J. A. Crustal magma plumbing within a segment of the Mid Atlantic Ridge, $35^{\circ}$ N. Earth Planet. Sci. Lett. 175, $55-67$ (2000).

30. Scott, D. R. \& Stevenson, D. J. Magma solitons. Geophys. Res. Lett. 11, 1161-1164 (1984).

31. Reid, I. \& Jackson, H. R. Oceanic spreading rate and crustal thickness. Mar. Geophys. Res. 5, 165-172 (1981).

32. Phipps Morgan, J. \& Forsyth, D. W. Three-dimensional flow and temperature perturbations due to transform offset: Effects on oceanic crustal and upper mantle structure. J. Geophys. Res. 93, 2955-2966 (1988).

33. Blackman, D. K. \& Forsyth, D. W. in Mantle Flow and Melt Generation at Mid-Ocean Ridges (eds Phipps Morgan, J., Blackman, D. K. \& Sinton, J. K.) 311-326 (Geophysical Monograph 71, American Geophysical Union, Washington D.C., 1992).

34. Buck, W. R. \& Su, W. Focused mantle upwelling below mid-ocean ridges due to feedback between viscosity and melting. Geophys. Res. Lett. 16, 641-644 (1989).

35. Scott, D. R. \& Stevenson, D. J. A self-consistent model of melting, magma migration and buoyancy driven circulation beneath mid-ocean ridges. J. Geophys. Res. 94, 2973-2988 (1989).
36. Sotin, C. J. \& Parmentier, E. M. Dynamical consequences of compositional and thermal density stratification beneath spreading centers. Geophys. Res. Lett. 16, 835-838 (1989).

37. Pariso, J. E., Sempere, J. C. \& Rommevaux, C. Temporal and spatial variations in crustal accretion along the Mid-Atlantic Ridge $\left(29^{\circ}-31^{\circ} 30^{\prime} \mathrm{N}\right)$ over the last 10 m.y.: Implications from a 3-D gravity study. J. Geophys. Res. 100, 17781-17794 (1995).

38. Tucholke, B. E. et al. Segmentation and crustal structure of the western Mid-Atlantic Ridge flank, $25^{\circ} 25^{\prime}-27^{\circ} 10^{\prime} \mathrm{N}$ and 0-29 m.y. J. Geophys. Res. 102, 10203-10223 (1997).

39. Sparks, D. W., Parmentier, E. M. \& Phipps Morgan, J. Three-dimensional convection beneath a segmented spreading center: Implications for along-axis variations in crustal thickness and gravity. J. Geophys. Res. 98, 21977-21995 (1993).

40. Hirth, G. \& Kohlstedt, D. L. Water in the oceanic upper mantle: Implications for rheology, melt extraction and the evolution of the lithosphere. Earth Planet. Sci. Lett. 144, 93-108 (1996).

41. Braun, M. G., Hirth, G. \& Parmentier, E. M. The effect of deep damp melting on mantle flow and melt generation beneath mid-ocean ridges. Earth Planet. Sci. Lett. 176, 339-356 (2000).

42. Choblet, G. \& Parmentier, E. M. Mantle upwelling and melting beneath slow-spreading centers: Effects of variable rheology and melt productivity. Earth Planet. Sci. Lett. 184, 589-604 (2001).

43. Neumann, G. A. \& Forsyth, D. W. The paradox of the axial profile: Isostatic compensation along the axis of the Mid-Atlantic Ridge? J. Geophys. Res. 98, 17891-17910 (1993).

44. Detrick, R. S., Needham, H. D. \& Renard, V. Gravity anomalies and crustal thickness variations along the Mid-Atlantic Ridge between $33^{\circ} \mathrm{N}$ and $40^{\circ} \mathrm{N}$. J. Geophys. Res. 100, 3767-3787 (1995).

45. Hooft, E. E. E., Detrick, R. S., Toomey, D. R., Collins, J. A. \& Lin, J. Crustal thickness and structure along three contrasting spreading segments of the Mid-Atlantic Ridge, $33.5^{\circ}-35^{\circ} \mathrm{N}$. J. Geophys. Res. 105, 8205-8226 (2000).

46. Shen, Y. et al. Seismic evidence for a tilted mantle plume and north-south mantle flow beneath Iceland. Earth Planet. Sci. Lett. 197, 261-272 (2002).

47. Yang, X. \& Fischer, K. M. Constraints on North Atlantic upper mantle anisotropy from S and SS phases. Geophys. Res. Lett. 21, 309-312 (1994).

48. Prince, R. A. \& Forsyth, D. W. Horizontal extent of anomalously thin crust near the Vema fracture zone from the three-dimensional analysis of gravity anomalies. J. Geophys. Res. 93, 8051-8063 (1988).

49. Huang, M., Guan, Z., Zhai, G. \& Ouyang, Y. On the compensation of systematic errors in marine gravity measurements. Mar. Geodesy 22, 183-194 (1999).

50. Bonatti, E. et al. Steady-state creation of crust-free lithosphere at cold spots in mid-ocean ridges. Geology 29, 979-982 (2001).

Acknowledgements We thank A. Peyve and co-workers at the Geology Institute, Russian Academy of Science, and the captain and crew of the RV Akademic N. Strakhov for help with field work. We thank K. Kastens for providing cruise EW9305 gravity data; W. R. Buck and J. Karson for comments on the manuscript; and D.W. Forsyth for providing programs useful in processing gravity data. This work was supported by the Consiglio Nazionale Ricerche and the National Science Foundation.

Competing interests statement The authors declare that they have no competing financial interests.

Correspondence and requests for materials should be addressed to E.B. (enrico.bonatti@bo.ismar.cnr.it). 